\title{
Assessment of the Design for Organization production processes using fuzzy logic
}

\author{
Józef Matuszek ${ }^{1 *}$, Tomasz Seneta $^{1}$ and , Aleksander Moczała ${ }^{1}$ \\ 1 University of Bielsko-Biala, Faculty of Mechanical Engineering And Computer Science, Willowa 2, 43-309 \\ Bielsko-Biała, Poland,jmatuszek@ath.bielsko.pl, tomasz.seneta@zf.com, amoczala@ath.bielsko.pl; e-mail@e- \\ mail.com \\ *Correspondence: jmatuszek@ ath.bielsko.pl; Tel.: +48-338279253
}

Featured Application: new method to assess design for manufacturability based on fuzzy variables.

\begin{abstract}
The paper presents design methodology for the production process of a new product from the point of view of the assembly operations technology criterion (Design for Assembly - DFA) in the conditions of high-volume production. Mentioned are DFA methods and techniques used in the implementation of a new product. Author presents a new method to assess design for manufacturability based on fuzzy variables based on fuzzy variables. An example was given to illustrate the proposed course of action
\end{abstract}

Keywords: production process design, design for manufacturability, fuzzy logic.

\section{Introduction}

In the conditions of high production volume, when implement new products, less attention is due to the ever-wider technological possibilities of contemporary workplaces, workshop aids, automation, the high performance achieved and relatively low costs, devoted to the processing of elements, components of final products. Hence reported in literature advanced evaluation methods of products design manufacturability tailored to evaluate the implementation of a new product in the conditions of high volume mass production and are directed to processes for assembly. This is due to the high proportion of manual work compared to machining, which is associated with high labour intensity and high costs of assembly processes.

In the production of individual and small-batch main attention is paid to the issue of the possibility to implement the plant, the possibility of cooperative companies, as well as the determinants of the logistic flow of resources. Therefore, much attention is paid to the performance of the production cost target, taking into account investments in new production lines and positions, defined in terms of having to be carried out also other products and vision of the future production program [19].

\section{Production preparation process}

In the automotive industry, proposals for the use of design-oriented assessment methods for assembly. "Design for Assembly" - DFA, was described by G. Boothroyd and P. Dewhurst in the work "Design for Assembly, A Designers Handbook" in 1983. The concept of "Design for Assembly" can be defined in various ways, from the narrow meaning of "product design from the point of view of manufacturability criterion" to the broader term associated with "product and process design from the cost-effective criterion point of view and reliable manufacturing to ensure the state of customer satisfaction "[17]. Many DFA methods are presented in the literature. The chronology of these methods and their brief characteristics are presented in Table 1. [10,15,16]. 
Table 1. Summary and description of the methodology of selected Design of Assembly methods [17].

\begin{tabular}{|c|c|c|c|c|}
\hline $\mathrm{Nr}$ & Metoda & Rok & Odkrywcy & Opis \\
\hline 1. & Lucas DFA & 1980 & $\begin{array}{l}\text { Redford A. H., } \\
\text { Swift K. G. }\end{array}$ & $\begin{array}{l}\text { It is based on the assembly sequence } \\
\text { diagram (SSM) assess the assembly } \\
\text { design. Producibility is estimated on the } \\
\text { basis of penalty points associated with } \\
\text { the product installation problems. }\end{array}$ \\
\hline 2. & $\begin{array}{c}\text { Hitachi } \\
\text { Assemblability } \\
\text { Evaluation Method } \\
(\text { AEM })\end{array}$ & 1986 & $\begin{array}{l}\text { Miyagawa S., } \\
\text { Ohashi T. }\end{array}$ & $\begin{array}{l}\text { The method assesses the product's } \\
\text { assemblability and the cost index to } \\
\text { indicate project weaknesses. }\end{array}$ \\
\hline 3. & $\begin{array}{l}\text { Product } \\
\text { Assemblability Merit } \\
\text { Analysis Tool (PDM) }\end{array}$ & 1986 & Zorowski C. F. & $\begin{array}{c}\text { The method gives opinions on product } \\
\text { and component assembly problems and } \\
\text { oversize indicators in the project. }\end{array}$ \\
\hline 4. & $\begin{array}{l}\text { Boothroyd and } \\
\text { Dewhurst }\end{array}$ & 1988 & $\begin{array}{l}\text { Boothroyd G., } \\
\text { Dewhurst P. }\end{array}$ & $\begin{array}{l}\text { The method is based on determine the } \\
\text { costs associated with the manual or } \\
\text { automatic assembly process and has } \\
\text { three criteria for limit the number of } \\
\text { components. }\end{array}$ \\
\hline 5. & $\begin{array}{l}\text { Integrated Desing for } \\
\text { Assembly Evaluation } \\
\text { and Reasoning System }\end{array}$ & 1991 & $\begin{array}{l}\text { Sturges R. H. } \\
\text { Jr, Kilani M. I. }\end{array}$ & $\begin{array}{l}\text { The method built on the basis of solid } \\
\text { modelling, explores the possibility of } \\
\text { product assemblability. }\end{array}$ \\
\hline 6. & $\begin{array}{l}\text { Fuzzy Product } \\
\text { Assemblability Merit } \\
\text { Analysis Tool }\end{array}$ & 1993 & $\begin{array}{l}\text { Jackson S. D., } \\
\text { Sutton J. C., } \\
\text { Zorowski C. F. }\end{array}$ & PDM developed with fuzzy logic. \\
\hline 7. & DFA REV-ENGE & 1994 & $\begin{array}{l}\text { Kim G. J., } \\
\text { Bekey G. A. }\end{array}$ & $\begin{array}{l}\text { DFA method taking into account } \\
\text { reverse engineering. }\end{array}$ \\
\hline 8. & $\begin{array}{l}\text { Constraints Network } \\
\text { System }\end{array}$ & 1995 & $\begin{array}{l}\text { Oh J. S., Grady } \\
\text { P. O., Young } \\
\text { R. D. F. }\end{array}$ & Method of interrelated constraints. \\
\hline 9. & $\begin{array}{l}\text { Virtual Disassembly } \\
\text { Evaluation }\end{array}$ & 1998 & Srinivasan $\mathrm{H}$. & $\begin{array}{l}\text { Method taking into account virtual } \\
\text { disassembly. }\end{array}$ \\
\hline
\end{tabular}

The first and the second method are presented in the paper, due to the largest application in practice. Market conditions have forced companies to rationalize a comprehensive approach to the design and marketing of a new product [2,3,4,24]. The need for a broader look at the assessment of the technology of the structure, including this problem, taking into account many other aspects, this way of design is illustrated in Fig. 1. 


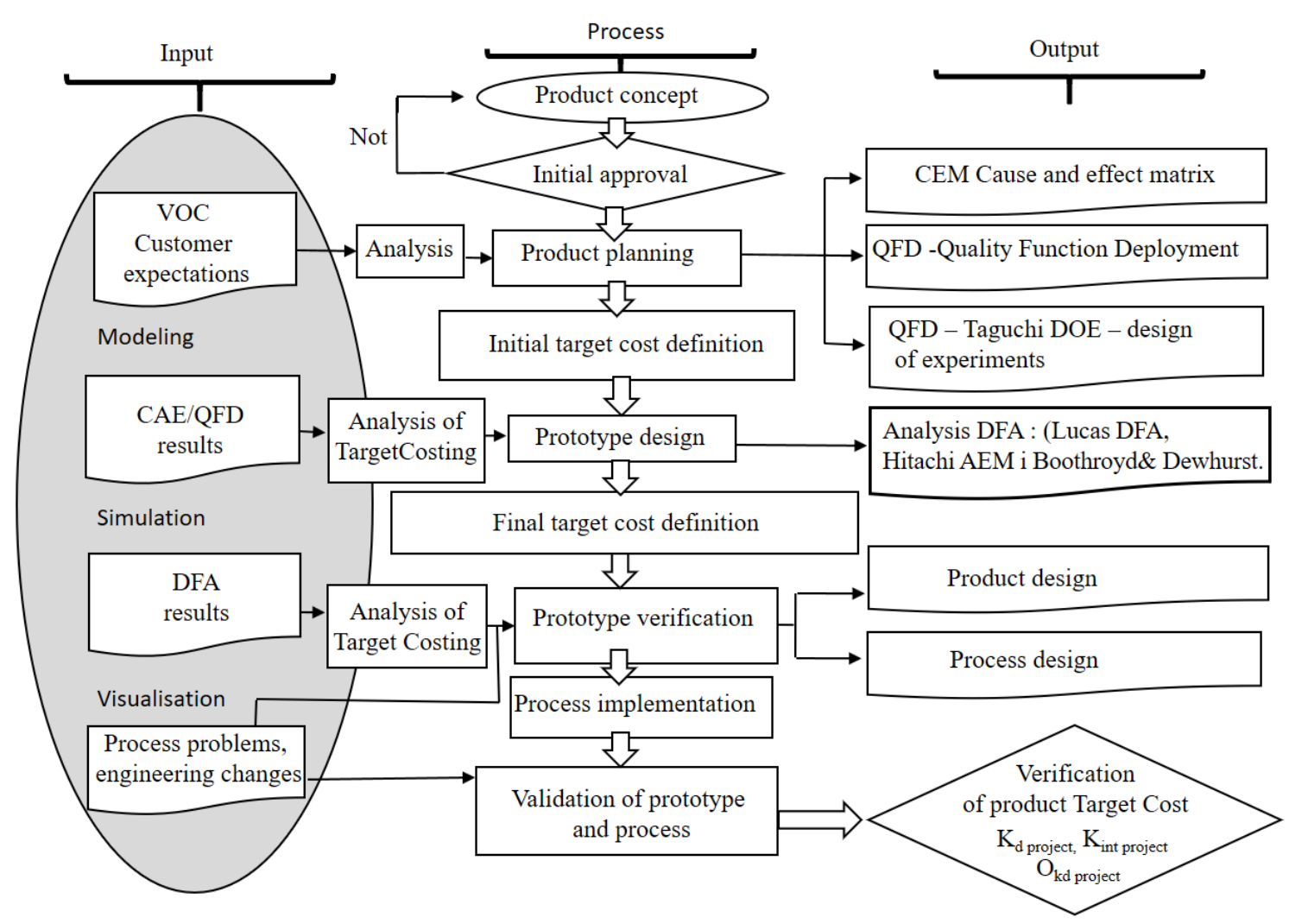

Figure 1. The use of methods to support the design of the production process of a new product.

In the design process under the aforementioned philosophies have been used methods such as QFD (Quality Function Deployment) $[1,9,13]$ using in processes of implement products customer requirements, FMEA (Failure Mode and Effect Analysis) [18] - related to the prediction and prevention of problems at the product design stage, DFX (Design for X) [24] - e.g. Design for Manufacturing (DFM) regarding the shaping of the design process of components and the product itself $[5,21]$. Decisions taken at the product design stage have a significant impact on production costs, efficiency and quality of production. Supporting methods such as modelling, simulation and animation of production processes and systems as well as stimulating innovation such as brainstorming, TRIZ is of great importance in carrying out these works $[8,10,14]$.

\section{The project according to the new integrated DFA method based on fuzzy inference}

\subsection{Assumptions for the new DFA method}

The justification for the emergence of a new fuzzy method for assess the technology of the structure results from the observed lack of flexibility of the described methods of BoothroydDewhurst and Lucas. These methods were created in the 1980s in the conditions of needs of the economy focused on serial and mass production. The current development of the economy and technology means that the modern economic system is characterized by a much greater need for flexibility in terms of production methods: high volume, low volume and unit. The need to create a more flexible method adaptable to the type of production is noticeable[3].

The design process should be determined from the point of view of various usability criteria Fig. 2. The assessment should take into account many other various factors, sales, service, spare parts availability, production series, types of equipment, available assembly techniques, level of automation, cooperative services, possibilities of application commercial components, crew technical culture, etc. In small-lot and serial production conditions, the design process of new product production is based on simplified production documentation. Due to the low production series, production data result from the project are rarely verified at the production stage, while the 
experience gained from this stage is used in the production projects of new products. In relation to mass production and mass production, particular attention from the point of view of cost criterion is paid to: the possibility of using unified and standardized elements included in the final product, the use of work stations and workshop aids for processing and assembly of various elements included in the products making up the program production and introduction of group machining processes, process phases, group operations for various elements [11,22]. The newly proposed method using fuzzy inference is characterized by such flexibility.

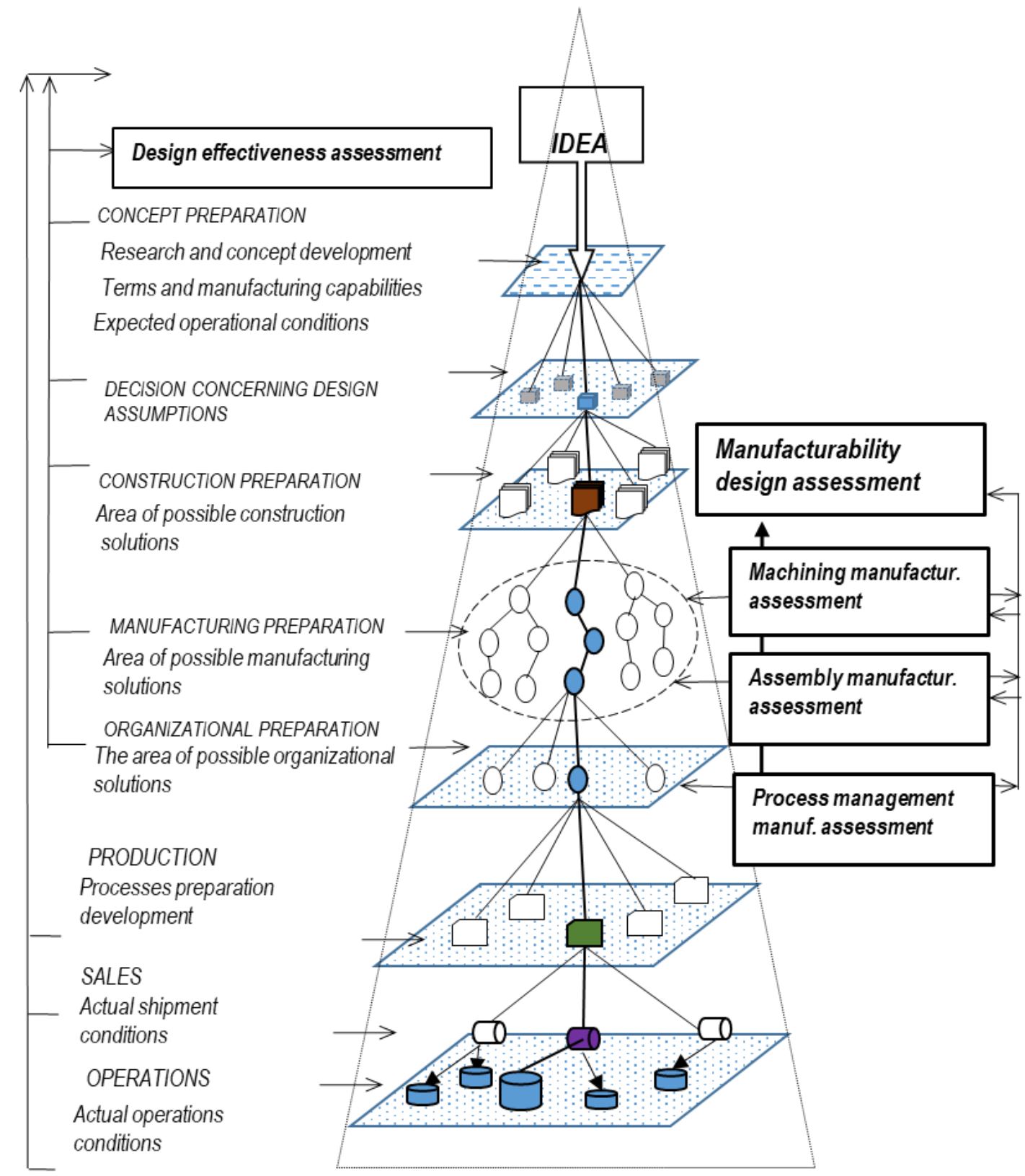

Figure 2. Modified design and development process for the production of a new product

\subsection{The course of the new DFA method}

The product design analysis process is carried out by experts representing as experts: product design, machining process design, assembly process design, quality assurance, product cost analysis, $\mathrm{OHS}$ and environmental protection in accordance with Figures 3 and 4. 


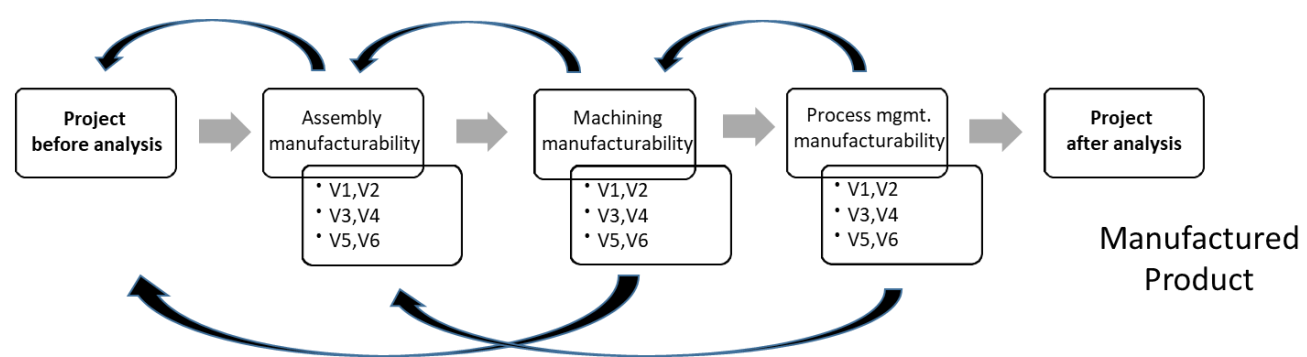

Figure 3. Structural analysis of the structure's technology in the proposed method.

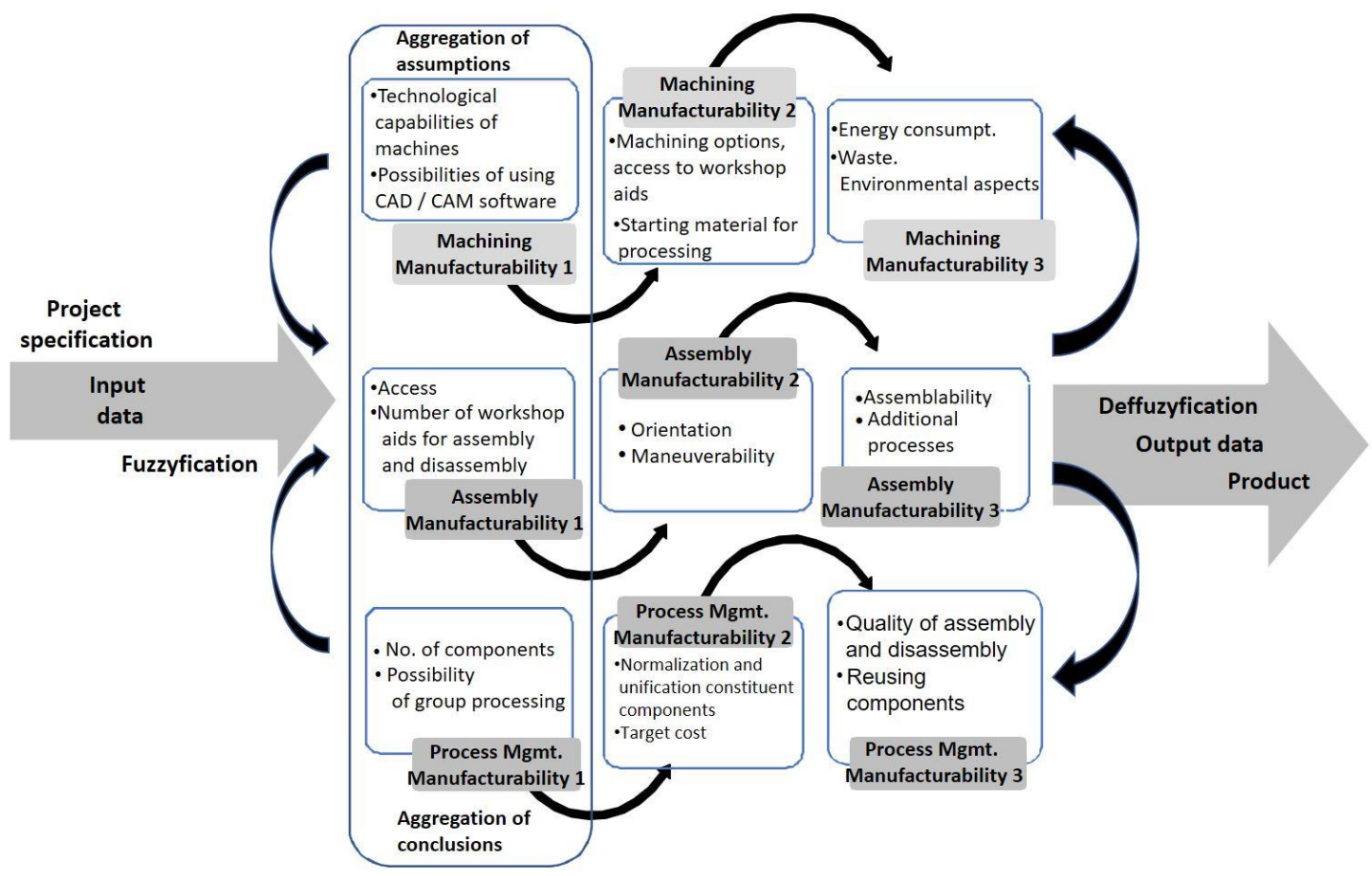

Figure 4. Model of the new DFA method based on three successive stages and sub-stages of fuzzy inference.

Experts determine the use of method tables, e.g. Boothroyd or Lucas, in accordance with the order of the process for each component of the product design, make an assessment on a scale of 0 to 100 . Then the process of the machining process and the assembly process are evaluated. The method was developed on the basis of the proposed General Scheme of Technology Assessment and consists of three stages: assessment of machining efficiency, assessment of assembly efficiency, assessment of production organization efficiency.

The assessment is related to the set of linguistic variables $\mathrm{Vi}=\{\mathrm{V} 1, \ldots, \mathrm{Vn}\}$, and $\in \mathrm{N}-\{0\}$, defining the input and output criteria of technology. The linguistic variable Vi is described by a quadrangle:

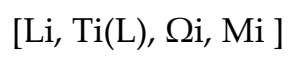

where $: \mathrm{Li}_{i}=\left\{\mathrm{L}_{1}, \ldots, \mathrm{Ln}_{n}\right\}, \mathrm{i} \in \mathrm{N}-\{0\}-$ set of linguistic variable names, $\mathrm{T}_{\mathrm{i}}\left(\mathrm{L}_{\mathrm{i}}\right)=\left\{\mathrm{T}_{1}\left(\mathrm{~L}_{1}\right), \ldots, \mathrm{T}_{n}\left(\mathrm{~L}_{n}\right)\right\}, \mathrm{i}$ $\in \mathrm{N}-\{0\}-$ set of countable determinations of linguistic variables, $\mathrm{tij}=\{\mathrm{t} 11, \mathrm{t} 12, \ldots, \mathrm{tnm}\}$, $\mathrm{i}, \mathrm{j} \in \mathrm{N}-\{0\}, \mathrm{tij} \subset \mathrm{Ti}(\mathrm{Li})$ - set of linguistic values of linguistic variables, $\Omega \mathrm{i}=\{\Omega 1, \ldots, \Omega \mathrm{n}\}$ , $i \in \mathrm{N}-\{0\}$ - set of linguistic ranges of variables $\mathrm{Vi}, \mathrm{Mi}=\{\mathrm{Mi}, \ldots, \mathrm{Mn}\}, \mathrm{i} \in \mathrm{N}-\{0\}$ - set of semantic rules, $\mathrm{mij}=\{\mathrm{m} 11, \mathrm{~m} 12, \ldots, \mathrm{mmn}\}$, and $, \mathrm{j} \in \mathrm{N}-\{0\}, \mathrm{mij} \subset \mathrm{Mi}-$ range of variation in linguistic value tij with an assessment of belonging from 0 to 1 [12].

The assessment of machining processability and subsequent assembly technology assessment correspond to the prototype stage during product design and development, and the assessment of 
production organization technology corresponds to the plot series and production series during validation and then serial production. The applied variables V1, V2, V3, V4, V5, V6 in the scope of machining technologies, assembly, production organization are shown in Fig. 4. The assessment, depending on the scope of information obtained, can be carried out for individual components of the product, groups of elements, its assemblies or also in a holistic way[12].

\section{Example}

\subsection{Input assumptions}

Based on the analyzes of the above methods of assess the product's producibility, an improved proprietary approach was proposed in the process to shape the product's productiveness. The illustration of the presented proposals is presented on the example of a single-stage gear in Fig 5 . General purpose gearboxes are designed in the form of a series of types from the point of view of market demand, production costs and delivery time to the customer. The gearbox shown in Fig. 5 was designed in a traditional way (welded body, a large number of bolted joints, etc.).

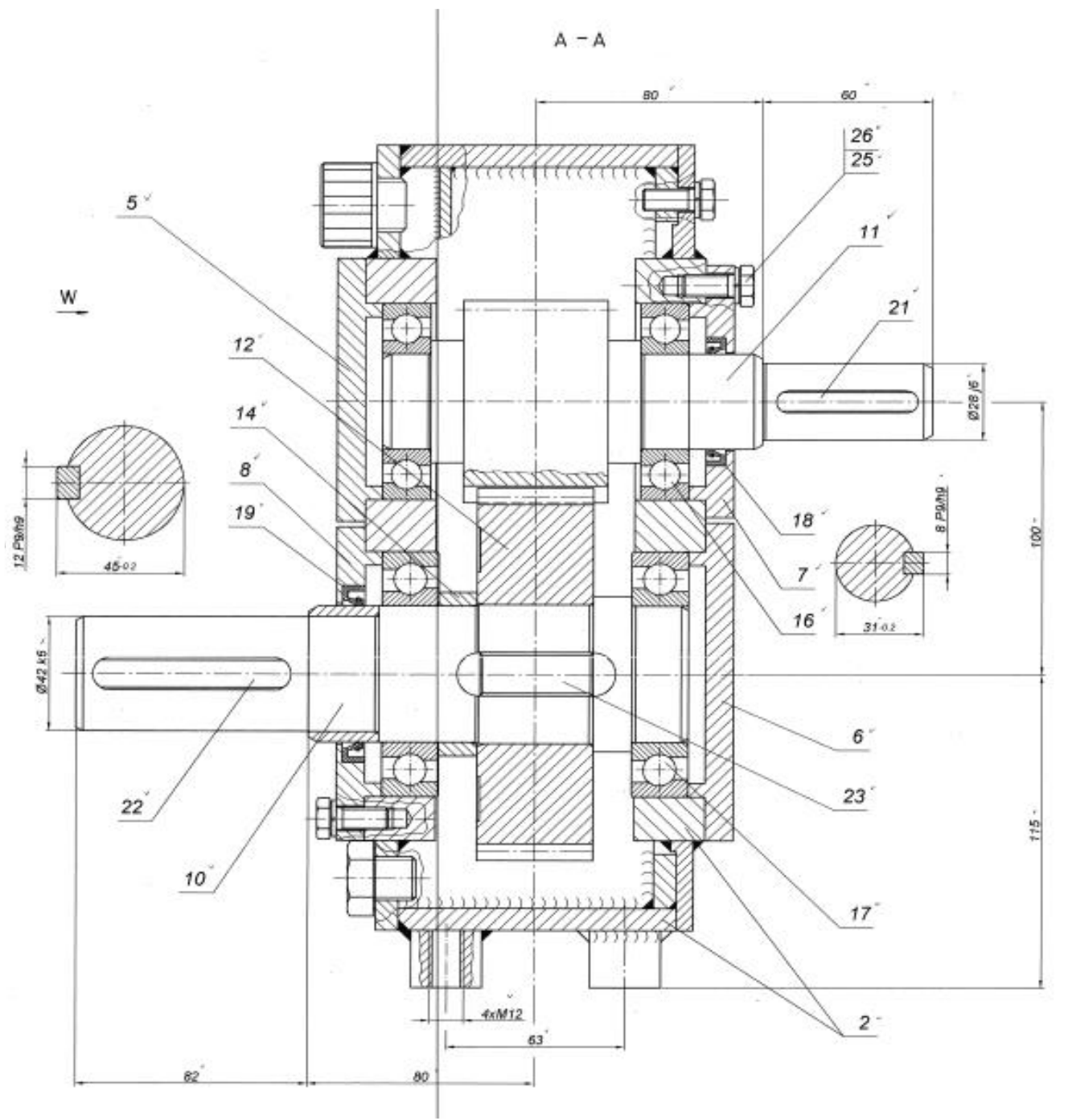

Figure 5. Diagram of the analyzed gearbox, 2- body, 5, 6, 7, 8- bearing caps, 10- shaft, 11-pinion, 12-tooth gear, 14- spacing rings, 17, 16- bearings, 18, 19, - seals, 21, 22, 23- keys, 25, 26-washers, screws.

\subsection{Fuzzy assessment of design for machinability - for example}

To decrease the number of components of a product may increase its complexity and increase its manufacturing costs. The final product can be easy to assemble and expensive to process its components. 
The condition for the correct determination of the cost-related factors involved in the production process of a given element is information about the characteristics that this element has from the point of view of construction, production and organization of production. The main task that must be performed is to determine the value of the costs of implementing individual operations. The cost of product processing and organization of production includes material costs, costs of cooperation and processing of a given operation. Classification of elements should include its type, e.g. shaft, sleeve, specify dimensions, accuracy of workmanship, etc. Based on technological similarity, the costs of individual operations can be determined in accordance with the data in the database of costs of operation of technologically closest components [7,20,22,23].

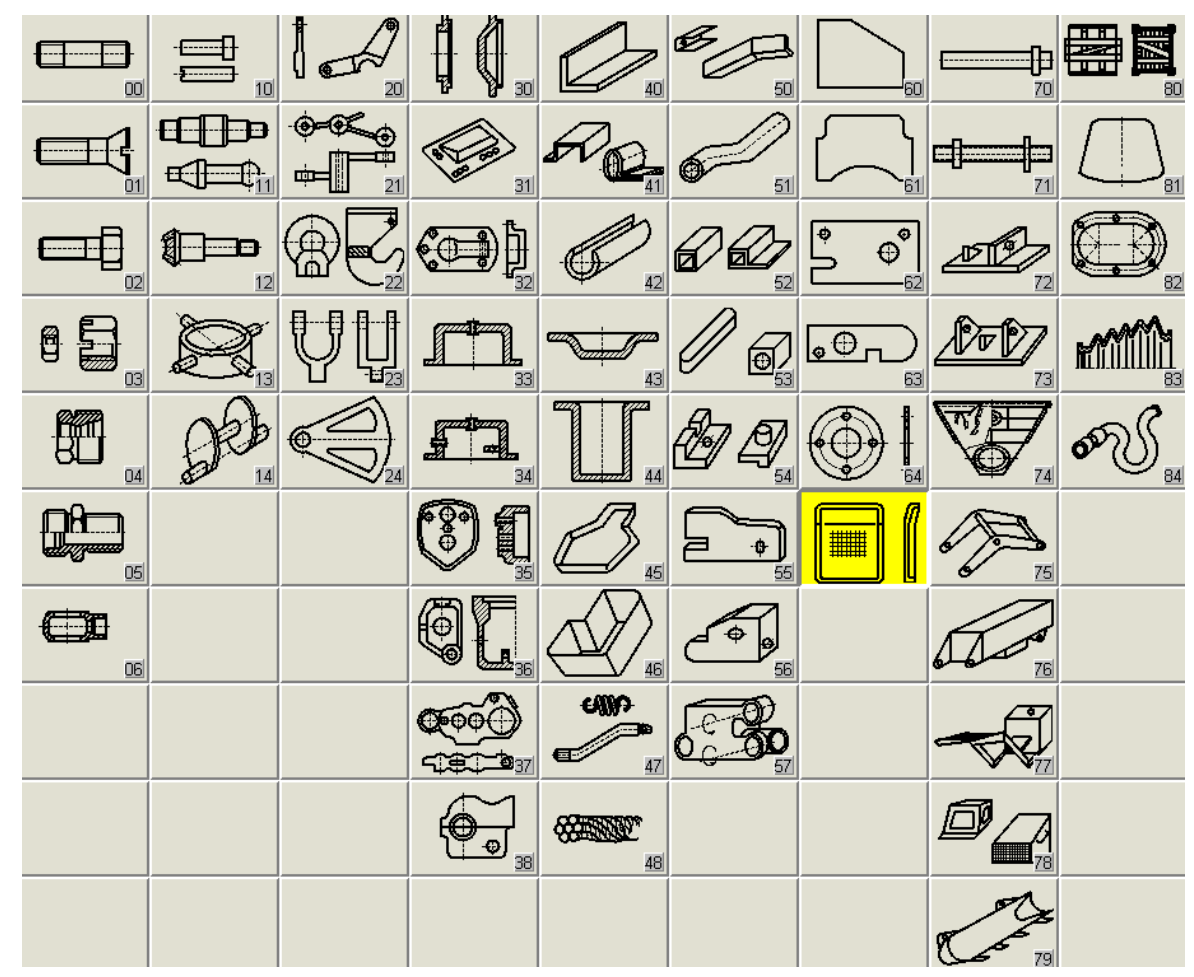

Figure 6. Example of the first level of the production item classifier- restrictions on unnecessary diversity.

The assessment is based on a multi-level classification of elements, assemblies made in the enterprise, etc. - Fig. 6. The new element is assigned to a given shape representative based on the designer's decision - Fig. 4. Based on the shape and design parameters from the manufacturing processes database, the process of the element with the same shape code and parameters most similar to the parameters of the new element is searched. Having the process of manufacturing the nearest element at your disposal and data on the value of cost factors in connection with the cost calculation system, you can specify the production costs of the designed element $[12,17,20]$.

For example, the assessment of body technology, assume that it depends on two factors, which are: technological capabilities of the machine park and the possibility of using CAD / CAM software, experts rated: technological capabilities $=20$, software capability $=55$. Aggregations of both parameters are shown in Fig. 7 and 8 [6,10]. 


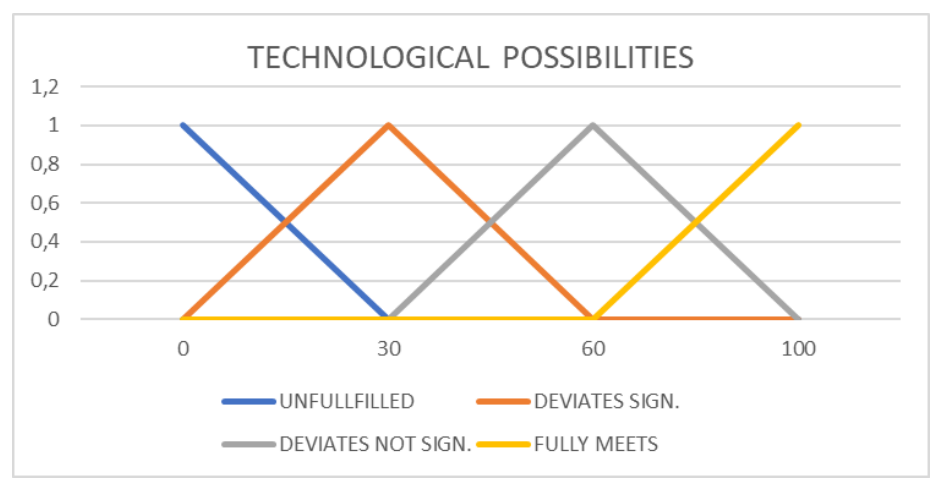

Figure 7. Graphical representation of linguistic variables for Technological Capabilities

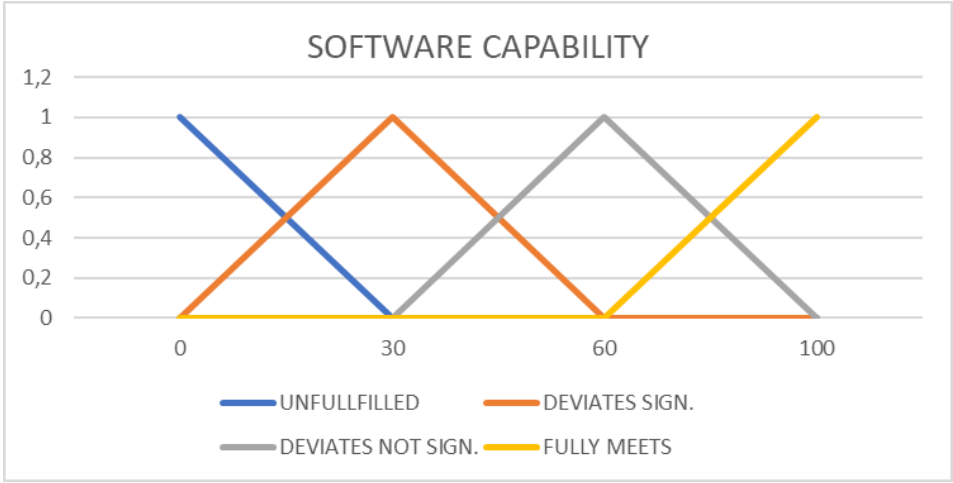

Figure 8. Graphical representation of linguistic variables for Software Capability

Aggregation of rules for Design for Machining Technology 1 was presented in Fig. 16

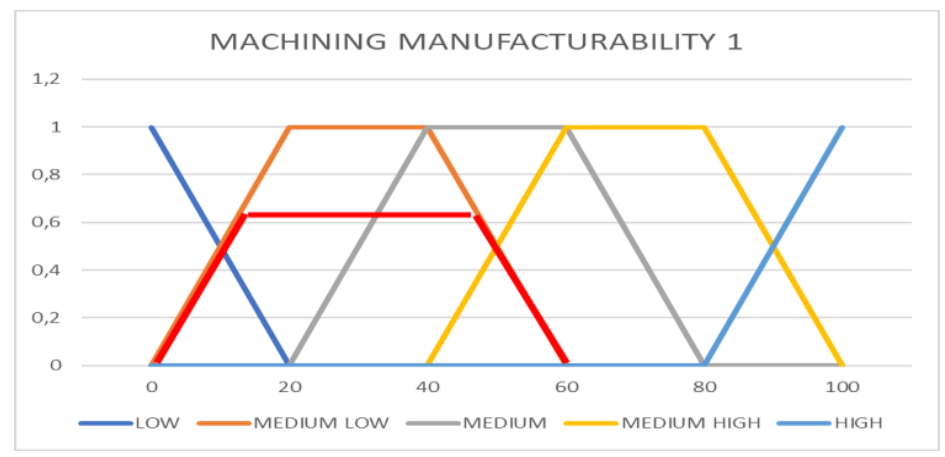

Figure 9. Aggregation of rules for Machining Technology 1

The Design for Machining Technology - Machining Processing Assessment for sub-step 1 is 29.9.

\section{Design for Machining Processing - Assessment 2}


In a similar procedure, the assessment was determined: Tool Machining Capability $=10$, Compliance Requirements = 35. Aggregation of rules for Machining Processing 2 is given in Fig. 10 .

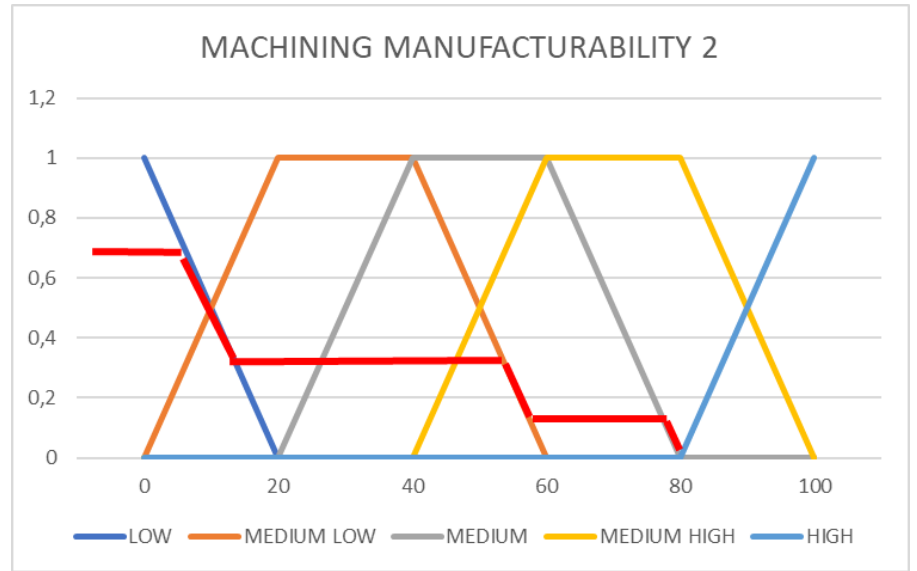

Figure 10. Aggregation of rules for Machining Technology 2

The value of Technology (Design for Machining Processing - Assessment 2) is 30.6.

\section{Design for Machining Processing - Assessment 3}

Assume that the assessment depends on two factors: experts have established the assessment: Energy consumption $=70$, Waste, environmental aspects $=10$. Technology 3 takes the value for Technological Capabilities in 70 and Software Capability 10:

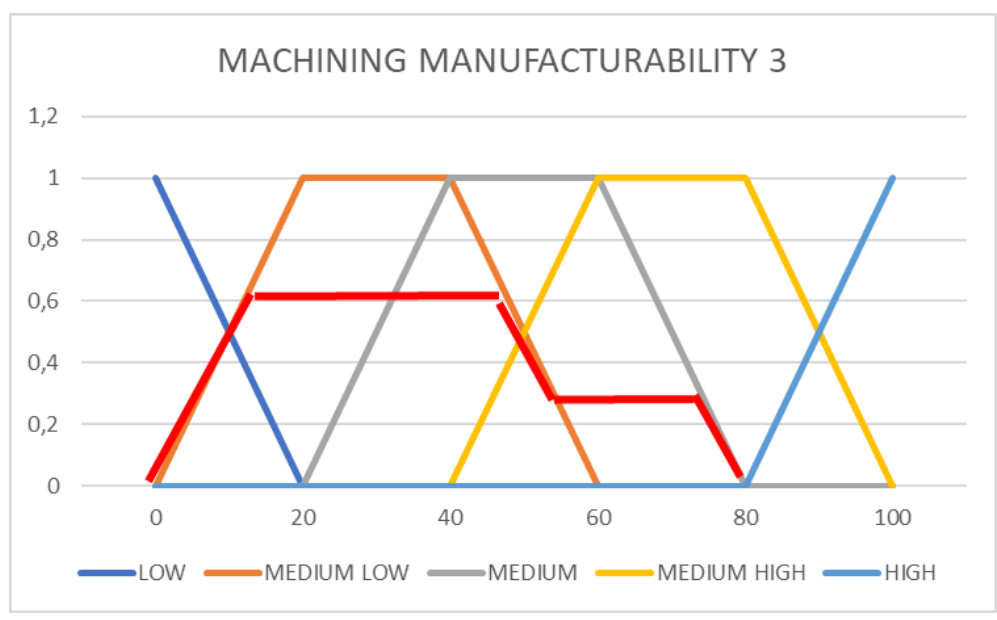

Figure 11. Aggregation of rules for Design for Machining Technology 3

Design for Machining Processing - Assessment Technology 3 value is 36.

\subsection{Fuzzy assessment of the design for manufacturing organization}

\section{Assessment of Design for Manufacturing organization 1}

The body's technology, assume that it depends on two factors, which are: Number of components and The possibility of group processing, experts have determined the rating as Number of components $=20$, The possibility of group processing $=20$. Technology 1 takes: 


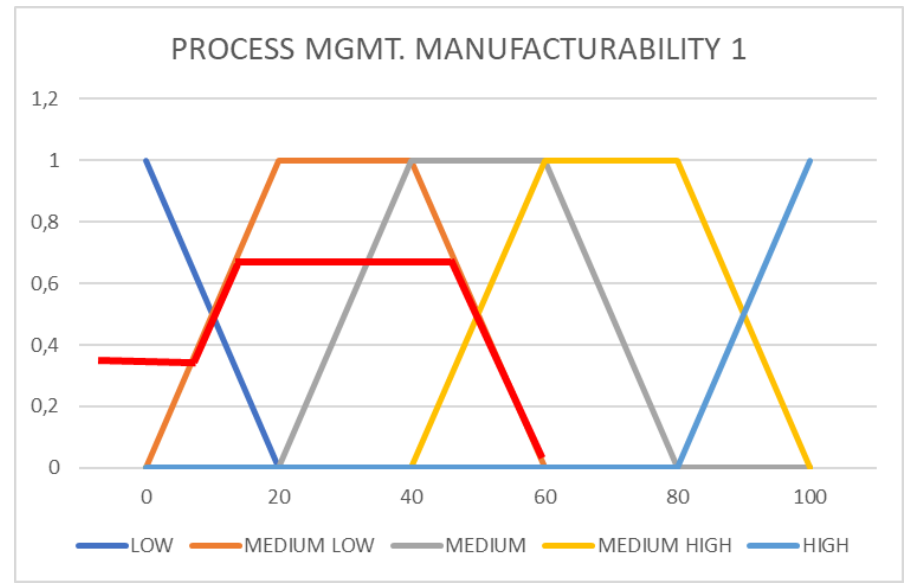

Figure 12. Aggregation of rules for Process management manufacturability1

The value of Process management manufacturability 1 for the value for Disassembly 20 and The possibility of group processing 20 is 40 .

\section{Assessment of Design for Manufacturing organization 2}

Technology depends on two factors, which are: Component normalization, Target cost. The expert group made the following assessment: Component unification $=20$, Target cost $=55$.

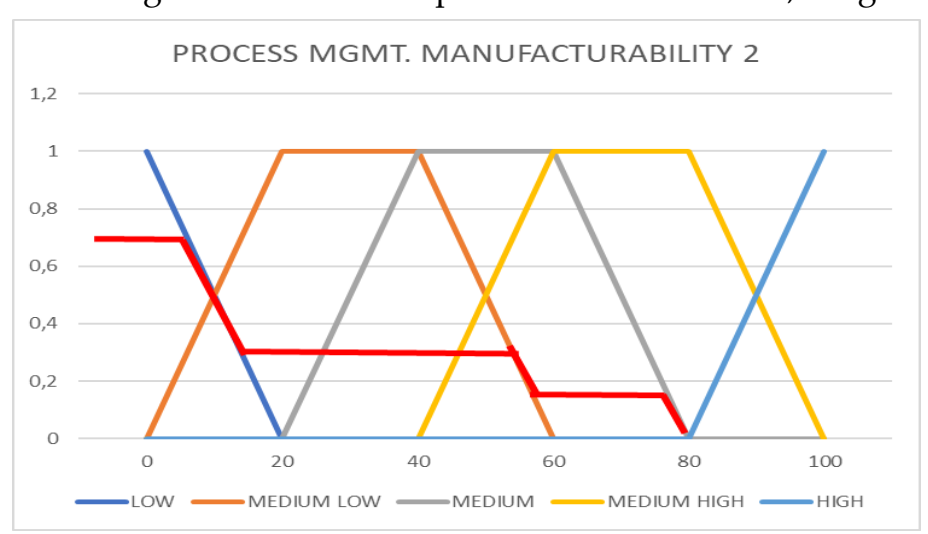

Figure 13. Aggregation of rules for Process management manufacturability (organization) 2

The value of Process management manufacturability - 2 is 31 .

\section{Assessment of Design for Manufacturing organization 3}

The technology of the 3rd component is determined, assume that it depends on two factors, which are: quality of assembly, Reuse components. Experts have determined the following: Quality of assembly $=70$, Reuse components $=10$.

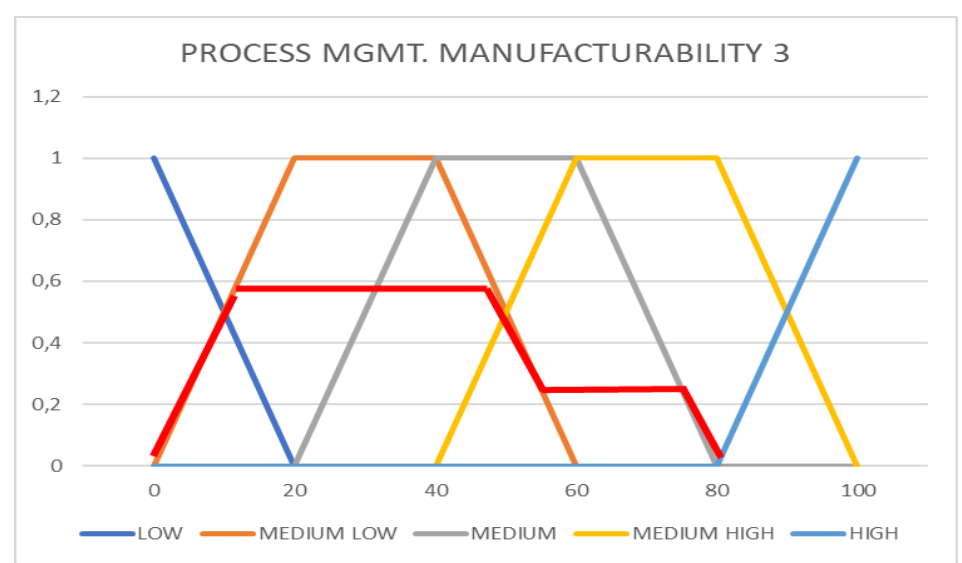

Figure 14. Aggregation of rules for assessment of Design for Manufacturing organization 3 
The Value of Assessment of Design for Manufacturing orgsnization 3 was 36.

\subsection{A fuzzy assessment of design fortechnology}

A complete fuzzy analysis of the technology was carried out in the same stages as for the sample "body" component. Each component of the analyzed transmission was assessed by a group of experts according to their best knowledge in the field of technology, organizational and cost options. Expert assessments were entered in Table 1. and are used in subsequent stages as input to fuzzy analyzes. The table contains a summary of all stages for each component. The stages of the analysis are identical to those presented above. Calculations of the fuzzy technology assessment method were made using the Fuzzy Logic Toolbox package, which is an addition to the Matlab program. The analysis selected a uniform representation of the membership function. It can be obtained by using a membership function with a uniform shape and parametric definition of the function. In the case of the aforementioned assessability of technology, triangular and trapezoidal functions were used. This is justified by the ease of obtaining a parametric description of the membership function, the minimum amount of memory needed for its storage, and the efficiency of processing.

For each group of components, calculations were made using the above scheme using Matlab R2017b - the "Fuzzy Logic Designer" module. The results are shown in Table 2.

In order to make the method comparison with traditional methods transparent, the evaluation and results were scaled. The best theoretical value for the design feasibility of the structure may be 100. After scaling, this rating may have a maximum value of 1.00 . The assessments of the efficiency according to the new method will be equal to $x / 100$ where $x$ is the given assessment of the structure's efficiency.

The development of an approximate representation of knowledge and fuzzy inference methods enables the construction of models for assessing technology to support decision making in conditions of uncertainty and lack of complete information about the problems being solved.

Premises and conclusions in these systems were developed using fuzzy logic elements. The knowledge contained in the system should come mainly from a field expert, and the effectiveness and efficiency of the system operation depend mainly on the ability to model this knowledge by the system designer. The elements of fuzzy logic presented in the article are used in solving tasks in the field of technological preparation of production. An important problem is the correct definition of fuzzy sets by determining for them the course of belonging functions. [source-Fuzzy Logic Toolbox user's guide]

Table 2 presents a summary of the results of individual components obtained in the fuzzy transmission analysis. An acceptability criterion of 0.55 was adopted for each component (modeled on the recommendations of the Lucas method and other DFA methods as well as the opinions of experts from industrial practice), elements of lower value should be redesigned. The following transmission components need to be redesigned as a result of the above assessment: body, cover, breather, oil level indicator, covers, additional processes, nameplate, shaft assembly and inlets. Elements rated as not requiring redesign are: gears, bearings, washers, screws.

An additional tool useful in the assessment of construction are surface charts - "Surface Viewer". With the help of such charts, we can quickly obtain the result of the Technology component without the need for complex calculations. In the chart below "Assembly technology 1" if, for example, the "Access" rating would change from 0.55 to 0.75 and the "Number of workshop aids" rating changed from 0.2 to 0.8 , then from the surface chart in Fig. 15 we can read the value of Assembly technology 1 at the level of 0.6 . In the process of selecting variants to improve the technology, it is a very useful tool that allows you to assess quickly how potential product changes can affect the result of the technology. 
Table 1. Set of component assessments made by experts for established criteria

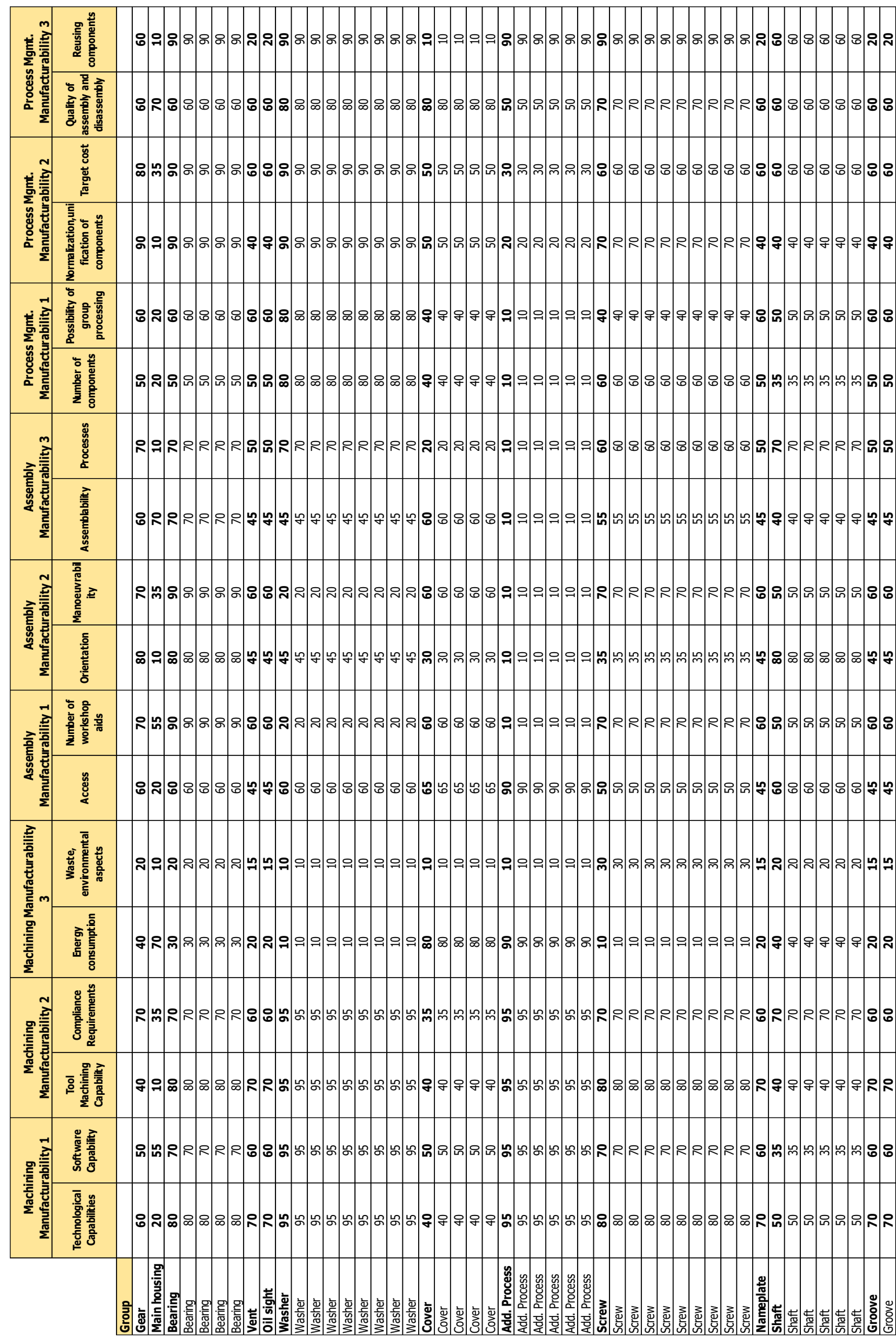




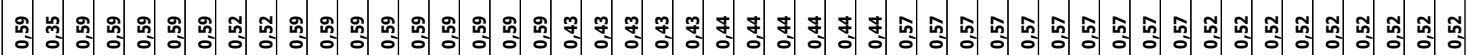

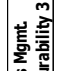

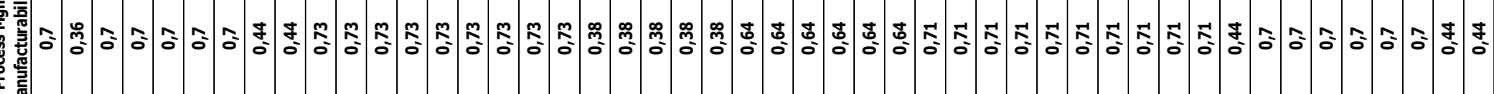

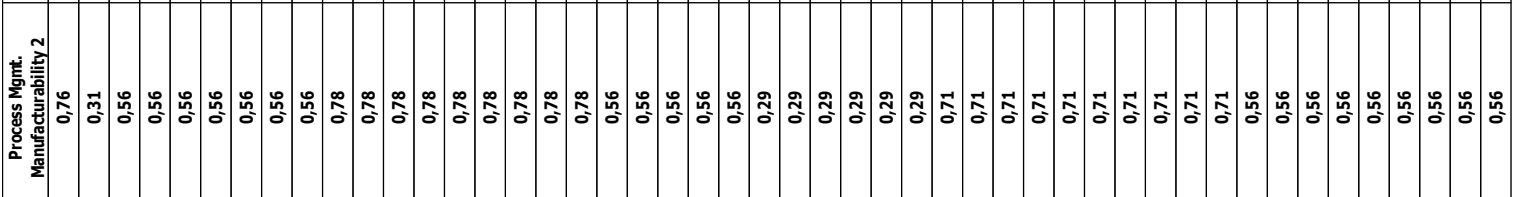
望

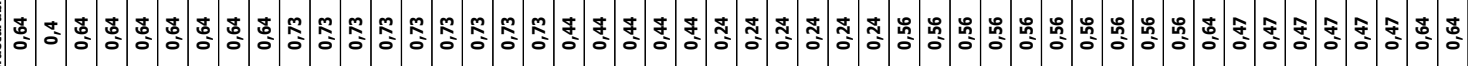
$\frac{10}{2}$

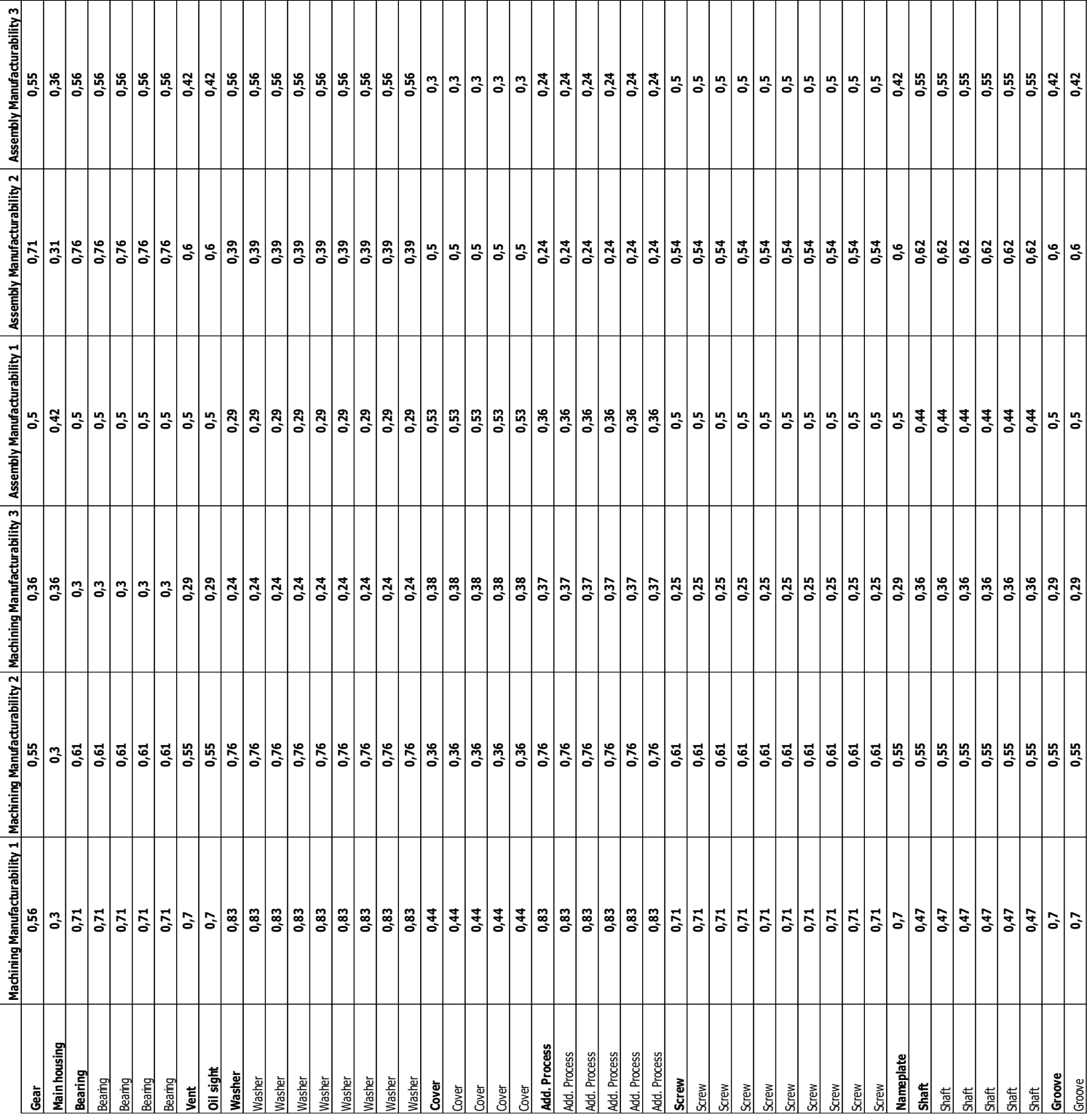




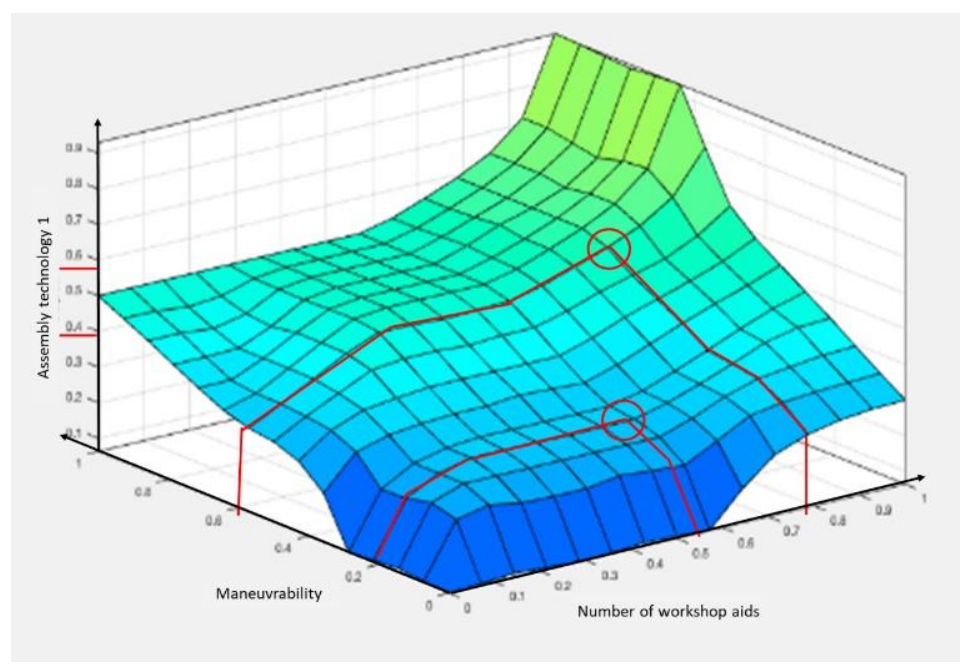

Figure 15. Surface Viewer - The surface of the dependence of the variable "Installation technology 1" on the input variables for "gears"

\subsection{Comparison of the use of methods on the example of a gear fragment - a drive shaft set}

In the study, the indicators of the assessment of the manufacturability of the structure were determined for the sample product presented in Fig. 5. As a result of the analysis after the proposed changes, the new form of the gear structure change is illustrated in Fig. 16. Fig. 17 presents the values of the indicators according to the traditional methods and the proposed method

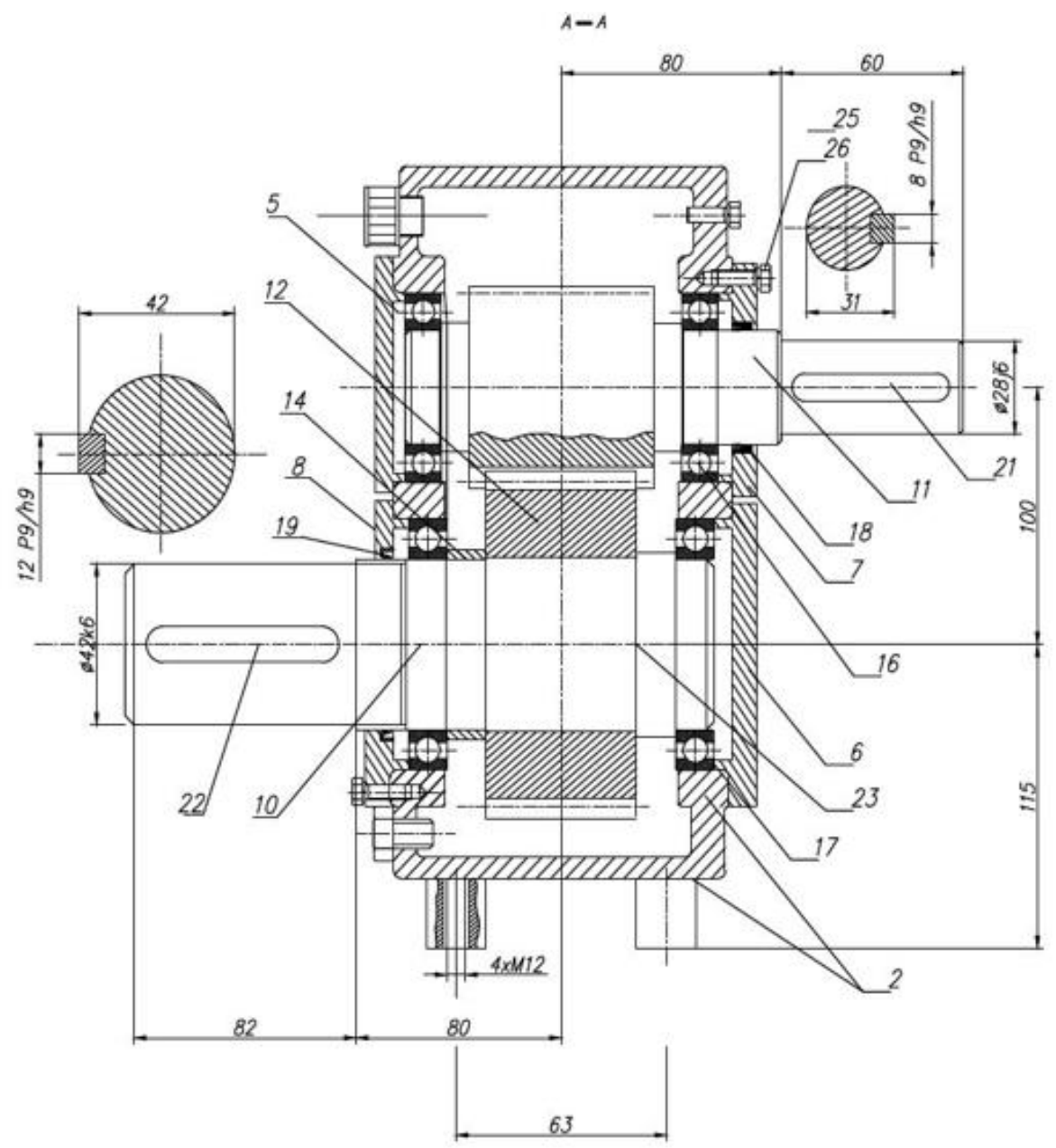

Figure 16. Construction form of the gearbox after the changes have been made 
Table 3. Comparison of DFA methods

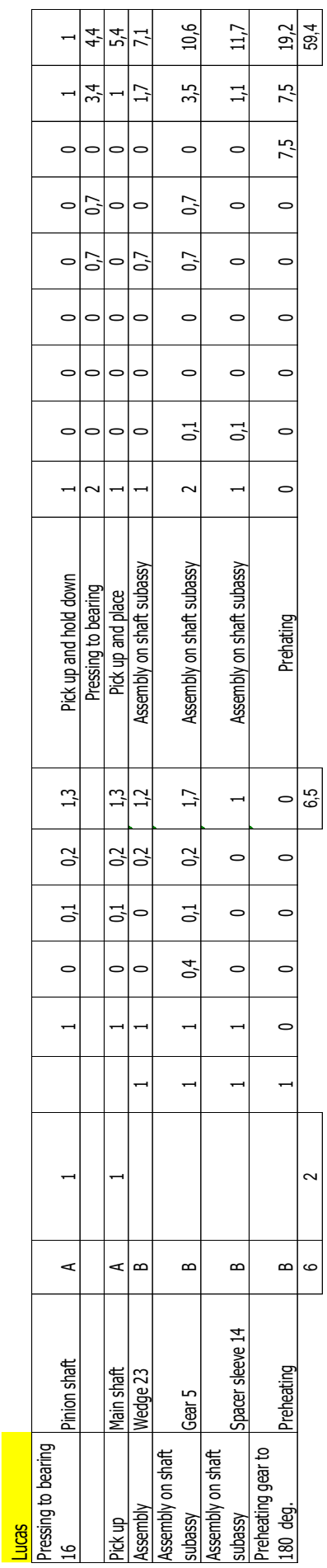

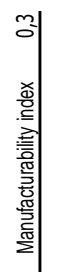

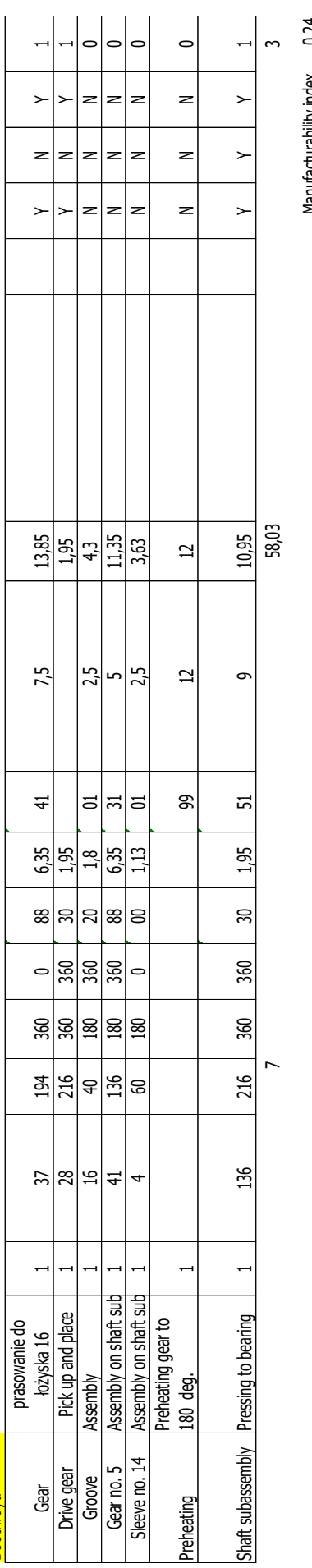

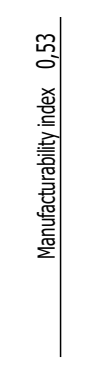

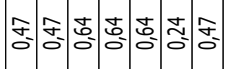

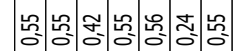

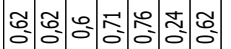

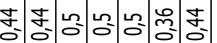

$\mathscr{2}$

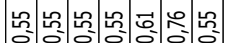

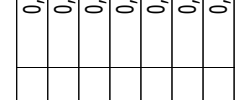

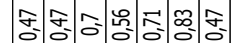

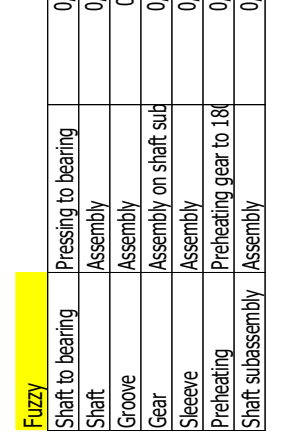

The result of a single method does not give a picture of effectiveness or not a new fuzzy method. For this purpose, a comparison of a selected transmission fragment of the new method and existing methods was carried out. From the overall assessment of the transmission, was selected fragment in the form of a drive shaft assembly and was compared in Table 3. Comparison shows that for small lot production assessment B\&D with 0,3 result, Lucas with 0,24 result versus Fuzzy defined for small lot with 0,53 result less restrictive approach of Fuzzy method. This is very important as small lot production usually has much less capital available. 


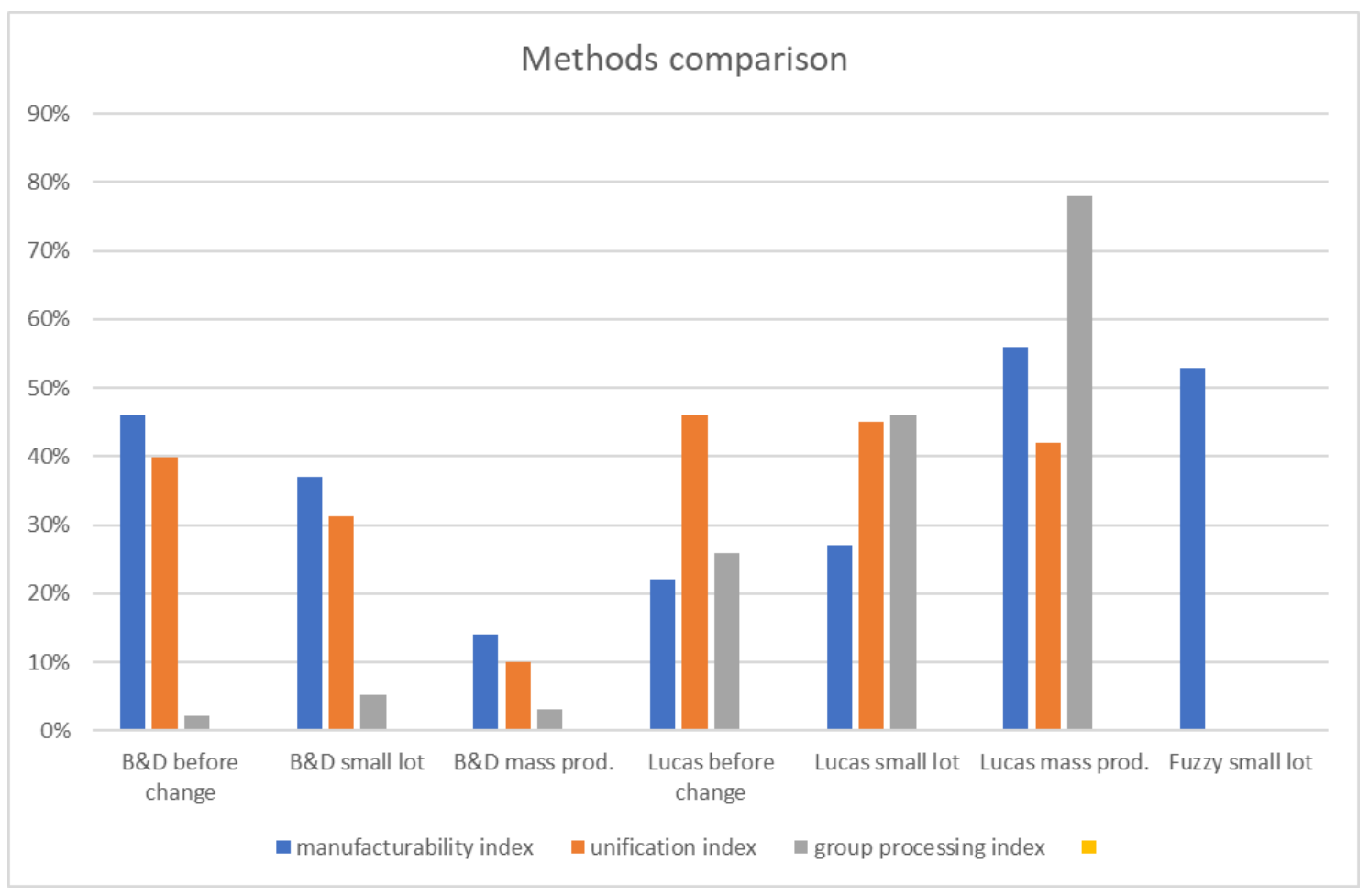

Figure 17. Comparison of methods for gear group.

The comparison should be read as follows, the lower the score, the more you need to redesign / reduce the product design. From the comparison of the assessment, it can be concluded that the Boothroyd \& Dewhurst method is the most stringent and focused on reduce / simplify the components of the project. At the same time, in the case of production not qualified for high-volume production, the result of such assessment may be a product with a small number of components, but a very complicated form, and therefore a high cost of processing and quality and other in the field of production organization. The Lucas method in a more balanced way assesses the above project, but the difference from Boothroyd-Dewhurst is not large, which means that it will also work best in mass production.

\section{Conclusions and comments}

In standard technology analyzes according to B\&D and Lucas DFA, it is associated with a reduction in the number of components that have no significant effect on the product's functions or their change consist in improvement in terms of assembly time and costs. In the traditional arrangement of the above mentioned the methods are oriented towards mass production. The proposed proprietary method based on the analysis of the obtained values of the parameters of the assessment of the efficiency of the entire process enables

- unification of components, application of group processing methods, standardization of machining and assembly operations, and thus save of investment in machines and shorter overall assembly time, shorten of times, elimination of errors, reduction of process costs

- taking into account, in addition to assembly, many other various factors, e.g. availability of spare parts, production seriality, production conditions in the form of equipment types, available assembly techniques, level of automation, scope of external cooperation orders

- the method can be used for smaller series of manufactured products,

- assessment of technology in the form of given indicators and coefficients should be carried out by experts with extensive production experience,

- arouse designers' creativity when designing new products, rationalizing works at the stage of improving and expanding the range of implemented production. 
The presented method is universal. The use of fuzzy logic gives the opportunity to express incomplete and uncertain information in natural language, in a simple way for humans based on expert knowledge and empirical data. The method takes into account the analysis of the production process in a holistic way.

\section{References}

1. Akao Y.: Quality function deployment (QFD). Integrating customer requirements into product design. 1990. Tom 369.

2. Andreasen M. M., Kähler S.: Lund Design for assembly. Lund: Ifs., 1988. Tom Ifs.

3. Boothroyd G., Dewhurst Design for Assembly. A Designers Handbook, 1983.

4. Boothroyd G.: Product design for manufacture and assembly. Computer-Aided Design. NJ: Elsevier, 1994. Nr 26(7), s. 505-520.

5. Boothroyd Product design for manufacture and assembly. Computer-Aided Design. 2010

6. Chu, W. S., Kim, M. S., Jang, K. H., Song, J. H., Rodrigue, H., Chun, D. M., ... \& Min, S. (2016). From design for manufacturing (DFM) to manufacturing for design (MFD) via hybrid manufacturing and smart factory: A review and perspective of paradigm shift. International Journal of Precision Engineering and Manufacturing-Green Technology, 3(2), 209-222, https://doi.org/10.1007/s40684-0160028-0, Electronic ISSN 2198-0810

7. Corsini, L., \& Moultrie, J. (2017). An exploratory study into the impact of new digital design and manufacturing tools on the design process. In DS 87-2 Proceedings of the 21st International Conference on Engineering Design (ICED 17) Vol 2: Design Processes, Design Organisation and Management, Vancouver, Canada, 21-25.08. 2017 (pp. 021-030), ISBN: 978-1-904670-90-2

8. El Wakil, S. D. - Processes and design for manufacturing. CRC Press, 2019, ISBN 978-1-138-58108-1

9. Evans J. R. I Lindsay W. The management and control of quality South. 1999.

10. Gebisa, A. W., \& Lemu, H. G. (2017). Design for manufacturing to design for Additive Manufacturing: Analysis of implications for design optimality and product sustainability. Procedia Manufacturing, 13, 724-731, https://doi.org/10.1016/j.promfg.2017.09.120, ISSN: 2351-9789

11. Herrmann, J. W., Cooper, J., Gupta, S. K., Hayes, C. C., Ishii, K., Kazmer, D., ... \& Wood, W. H. (2004, October). New directions in design for manufacturing. In ASME 2004 International Design Engineering Technical Conferences and Computers and Information in Engineering Conference (pp. 853-861). American Society of Mechanical Engineers Digital Collection, https://doi.org/10.1115/DETC2004-57770, ISBN: 0-7918-4696-2

12. Kacprzyk J., Pedrycz W. (Eds.). (2015). Springer handbook of computational intelligence. Springer., ISBN: 978-3-662-43504-5

13. Kehoe D.: Acceptance sampling. // The Fundamentals of Quality Management. - : Springer Netherlands, 1996, s. 226-227.

14. Lock Project Management. Ninth Edition. Hampshire, Great Britain: Gower Publishing Ltd, 2009.

15. Matuszek J., Seneta T.: Algorytmizacja procesu wdrażania nowego produktu w warunkach wielkoseryjnej produkcji. Mechanik. 2016, nr 7, s. 755-757.

16. Matuszek J: Inżynieria Produkcji. Wydawnictwo Politechniki Łódzkiej Filii w Bielsku-Białej, BielskoBiała 2000.

17. Miles B.L.: Design for Assembly - a key element within Design for Manufacture - Proc Inst Mech Eng, 1989. - No. 1: strony 29-38. - ISSN 0954-4070.

18. Palady P. I Olyai The status quo's failure in problem-solving. // Quality progress. - 2002. - Tom 35(8). strony 34-34.

19. Relich M., Śwíc A., Gola A. (2015) A Knowledge-Based Approach to Product Concept Screening. In: Omatu S. et al. (eds) Distributed Computing and Artificial Intelligence, 12th International Conference. Advances in Intelligent Systems and Computing, vol 373. Springer, Cham, Online ISBN 978-3-31919638-1 Swift, Ken G. Knowledge-based design for manufacture. Prentice-Hall, Inc., 1987. ISBN:978-013-516569-0

20. Shetty, D. and Ali, A. (2015), "A new design tool for DFA/DFD based on rating factors", Assembly Automation, Vol. 35 No. 4, pp. 348-357. https://doi.org/10.1108/AA-11-2014-088, ISSN: 0144-5154 
21. Swift, Ken G. Knowledge-based design for manufacture. Prentice-Hall, Inc., 1987. ISBN:978-0-13516569-0

22. Thekinen, J., \& Panchal, J. H. (2017). Resource allocation in cloud-based design and manufacturing: A mechanism design approach. Journal of Manufacturing Systems, 43, 327-338, https://doi.org/10.1016/j.jmsy.2016.08.005, ISSN: 0278-6125

23. Whitney D.E., Mechanical Assemblies - their design manufacture and role in product development: Oxford University Press, 2004. - 0-19-515782-6.

Yang K. I El-Haik B.S.: Design for six sigma. New York:: Mcgraw-Hill., 2003. - s. 184-186. 